\title{
Kronik Miyeloid Lösemi Tanılı Erkek Hastalarda İmatinib Tedavisinin Erektil Fonksiyonlar Üzerine Etkisinin Değerlendirilmesi
}

\author{
Evaluation of Affect on Erectil Functions of Imatinib in \\ Male Patients with Chronic Myeloid Leukemia
}

\author{
Atakan TEKINALP1 (ID) \\ ${ }_{1}$ Necmettin Erbakan Üniversitesi Tıp Fakültesi, Hematoloji Bilim Dalı, Konya, Türkiye \\ ${ }^{2}$ Uludağ Üniversitesi Tıp Fakültesi, Hematoloji Bilim Dalı, Bursa, Türkiye
}

öz

Amaç: İmatinib başta olmak üzere tirozin kinaz inhibitörleri (TKi) ile kronik miyeloid lösemi (KML)'de anlamlı sağkalım artışı ve moleküler yanıt elde edilmektedir. TKi'lerin teratojenik etkileri olabileceğinden tedavi altındaki kadınların gebelikten kaçınması önerilir. Hayvan çalışmalarında imatinibin spermatogenezi etkilediği ve diyabetik ratlarda diyabete bağlı erektil disfonksiyonlar (ED)'ın imatinib ile gerileyebileceği gösterilmiştir. Çalışmamızda erkek hastalarda imatinibin erektil fonksiyonlar üzerine etkisi araştırılmıştır.

Hastalar ve Yöntem: KML tanısıyla takip edilen erkek hastalardan KML dışında bir sistemik hastalık öyküsü olmayan, en az altı ay TKi kullanan, TKi dışında ilaç kullanmayan ve son altı ay içinde cerrahi öyküsü olmayan hastalar tespit edildi. Kullanılan TKI ilaç dozu ve süresi belirlendi. Hastaların erektil fonksiyonları Uluslararası Erektil Fonksiyon Değerlendirme İndeksi (IIEF-5) ile değerlendirildi.

Bulgular: Kriterlere uygun 31 hasta belirlendi. Hastaların 12 (\%38.7)'sinde ED saptanmadı. İmatinib kullanan 24 hasta değerlendirildiğinde ise 10 (\%41.5)'unda ED saptanmazken, 11 (\%45.8)'inde hafif, 3 (\%12.5)'ünde orta şiddette ED tespit edildi. ED ile imatinib dozu ve kullanım süresi arasında istatistiksel anlamlı bir bulgu elde edilmedi (sırasıyla $p=0.25$ ve 0.24 ).

Sonuç: Olgu sayısı sınırlı olmakla birlikte imatinib kullanımının ED'e neden olmadığı sonucuna varıldı.

Anahtar Kelimeler: Kronik miyeloid lösemi; İmatinib; Erektil disfonksiyon

\section{ABSTRACT}

Objective: The significant survival and moleculer response in chronic myeloid leukemia (CML) are obtined with treatment tyrosine kinase inhibitors (TKI) especially imatinib. Its recommended that fertile woman exposured to imatinib should avoid to get pregnancy because of teratogenicity affect of TKIs. Animal studies reported that imatinib has affecting on spermatogenesis and erectil dysfunctions (ED) occered due to diabet can reduce by treatment of TKIs. In this study, we investigated affect on erectil functions of imatinib in adult males.

Patients and Methods: We determined patients who had not any disease except of CML, had not used any drug except of TKI, used TKI least six months and had not history of surgery in the last six months among CML patients. The type of TKI, dosages and duration time of drug were assigned. Erectil functions were evaluated by using the International Index of Erectil Function (IIEF-5).

Results: We achieved 31 cases appropriated include criterias. Twelve (38.7\%) of cases had no ED. In 24 cases treated with imatinib, 10 (41.5\%) of cases had no ED, in contrast of 11 (45.8\%) of cases
Makale atıfı: Tekinalp A, Ali R. Kronik miyeloid lösemi tanılı erkek hastalarda imatinib tedavisinin erektil fonksiyonlar üzerine etkisinin değerlendirilmesi. LLM Dergi 2019;3(4):101-6.

\section{Yazıșma Adresi}

Dr. Öğr. Üyesi Atakan TEKiNALP

Necmettin Erbakan Üniversitesi Tıp Fakültesi, Hematoloji Bilim Dalı,

Konya-Türkiye

Geliş: 17.01.2020 - Kabul: 23.01.2020

E-posta: atakantekinalp@hotmail.com 
had mild- and 3 (12.5\%) of cases had moderate-degree ED. There was not statistical significance between ED and dosages of imatinib and dutation time of using imatinib (respectively $p=0.24$ and 0.24 ).

Conclusion: We obtained that exposuring to imatinib does not cause ED alhought the number of cases was limited.

Key Words: Chronic myeloid leukemia; Imatinib; Erectil dysfunction

\section{GíRiş}

Patogenezinde 9. ve 22. kromozomlar arasındaki translokasyon (Philadelphia kromozomu) sonucu oluşan füzyon geni ( $B C R / A B L$ füzyon geni) ve bu genin kinaz aktivitesi yüksek proteinlerinin rol oynadığı bilinen kronik miyeloid lösemi (KML), tüm erişkin lösemilerin \%15-20'sini oluşturur ve çoğunlukla ileri yaşlarda görülür. İyonize radyasyona maruz kalanlarda sık görülse de etyolojide suçlanan kesin bir ajan yoktur $(1,2)$. Olgular $\% 90$ oranında kronik faz ile kendini gösterir ve tanı anında \%30-50'si asemptomatiktir. Kromozomal anomali ile semptomların ortaya çıkışı arasında ortalama altı yıllık bir süre vardır. Tanısı periferik kan yayması, kemik iliği incelemesi, moleküler ve sitogenetik araştırmalarla kesinleştirilir (3). İnterferon, busulfan ve hidroksiüre başta olmak üzere çeşitli sitotoksik ajanlar kullanılmış fakat palyatif tedavi dışına çıkılamamıştır. 1970'li yıllarda allojenik kök hücre nakli ile kür şansı elde edilmiştir. 1998 yılında tirozin kinaz inhibitörü (TKI) olan imatinib mesilatın klinik uygulamaya girmesiyle KML'de imatinib dönemi başlamıştır. İmatinibe direnç gelişmesi ve yanıt kayıpları olması nedeniyle ikinci ve üçüncü kuşak TKi'ler gündeme gelmiştir.

Tirozin kinazlar hücre proliferasyonu, farklılaşması, motilitesi ve sinyal iletiminde önemli rol oynamaktadır. $\mathrm{Bu}$ nedenle tümöral gelişim baskılanmaktadır. İmatinib tedavisinde sıvı retansiyonu ve nonspesifik gastrointestinal yakınmalar dışında, tirozin kinazların hücresel etkileri düşünüldüğünde reprodüktif etkilerin de olması beklenebilir. Kadın hastalarda gonadal fonksiyonlarla ilişkili yapılmış bir çalışma söz konusu değildir ve bu etki bildirilmiş gebeliklerle sınırlı kalmaktadır $(4,5)$. Hayvan çalışmalarında imatinibin spermatogenezi etkilediği bildirilmekle birlikte, insan erkek fertilitesi ile ilgili veriler sadece TKi kullanan ve partnerlerinde gelişen gebeliklerle sınırlıdır $(5,6)$. Hormon ve erektil fonksiyonlar üzerine literatürde diyabetik ratlar

Tablo 1. IIEF-5 anketinde soruların ilgili konulara göre dağılımı (8)

\begin{tabular}{lcc} 
Bölüm & Sorular & Toplam skor \\
\hline Erektil disfonksiyon & $1,2,3,4,5,15$ & $6-30$ \\
Orgazmik fonksiyon & 9,10 & $0-10$ \\
Cinsel istek & 11,12 & $2-10$ \\
illişki tatmini & $6,7,8$ & $0-15$ \\
Genel tatmin & 13,14 & $2-10$ \\
\hline
\end{tabular}

dışında henüz kapsamlı bir çalışma ya da olgu bildirimi bulunmamaktadır. Çalışmamızda, takip ve tedavi altında olan erkek olgularda imatinibin erektil disfonksiyon (ED) etkisi yönünden değerlendirilmesi amaçlanmıştır.

\section{HASTALAR ve YÖNTEM}

Çalışmamız için 28.09.2010 tarihinde, 2010-9/8 sayısı ile Uludağ Üniversitesi Tıp Fakültesi Etik Kurulundan onay alındı.

Uludağ Üniversitesi Tıp Fakültesi İç Hastalıkları Anabilim Dalı Hematoloji Bilim Dalı tarafından takip edilen, KML tanılı 112 erkek değerlendirildi. En az altı ay TKi kullanan, son altı ay içinde cerrahi müdahale öyküsü olmayan, son bir aydır herhangi bir cinsel aktivite sorunu yaşamayan gönüllü hastalar çalışmaya dahil edildi. KML dışında bir hastalığa sahip, TKi dışında ilaç kullanan, altı ay içinde cerrahi operasyon geçiren ya da radyasyona maruz kalan, alkol ya da uyuşturucu madde bağımlılığı olan ve çalışmaya katılmak istemeyen hastalar dışlandı. Dahil edilme kriterlerine uygun 31 hasta yaş, tedavi süresi, kullanılan TKi ve dozu açısından değerlendirildi. Ayrıca bu hastaların hemoglobin, total lökosit sayısı, trombosit, açlık kan şekeri, total kolesterol, LDL kolesterol, HDL kolesterol ve trigliserid değerleri de kaydedildi.

Erektil fonksiyon değerlendirmesi, Rosen ve arkadaşlarının 1997 yılında geliştirdiği ve Akkuş ve arkadaşlarının prevalans çalışması için Türkçeleştirdiği Uluslararası Erektil Fonksiyon Değerlendirme İndeksi (IIEF-5) ile yapıldı $(7,8)$. IIEF-5 anketi toplam 15 sorunun yer aldığı beş ana bölümden oluşur. İlk beş soru ve 15. soru ED ile, diğer sorular orgazmik fonksiyon, cinsel istek, ilişki tatminliği ve genel tatminlikle ilişkilidir. Soruların ilgili konulara göre dağılımı Tablo 1'de belirtildi (8). IIEF-5, Türkçe'nin de aralarında yer aldığı 32 dile çevrildi. Hasta ve kontrol gruplarıyla yapılan çalışmalarda ED'i olan ve olmayan erkekleri ayırt etmede güvenilir olduğu gösterildi (9). İlk beş ve 15 . soruları içeren ED değerlendirmesinde her sorunun cevabı 1-5 arasında bir puana karşılık gelir. Sonuçta 6-30 arasında değişen bir toplam puana ulaşılır. Buna göre ED olup olmadığı gösterilir ve eğer disfonksiyon saptanmışsa derecesi hafif, orta ve ağır şeklinde sınıflandırılır. Toplam puana göre ED sınıflaması Tablo 2'de görülmektedir.

\section{İstatistiksel Analiz}

Elde edilen veriler SPSS for Windows 16.0 istatistik programıyla analiz edildi. Değerler arasındaki ilişkinin in- 
Tablo 2. IIEF-5'in erektil disfonksiyon ile ilişkili değerlendirmesi (8)

\begin{tabular}{ll} 
Toplam puan & Erektil disfonksiyon sınıflaması \\
\hline $6-10$ & Ağır \\
$11-17$ & Orta \\
$18-25$ & Hafif \\
$26-30$ & Erektil disfonksiyon yok \\
\hline
\end{tabular}

celenmesinde Spearman's korelasyon testi, kategorik değerlerin karşılaştırmasında Pearson ki-kare testi ve Fisher kesin ki-kare testi kullanıldı. İstatistiksel sonuçlar $\mathrm{p}<0.05$ olduğunda anlamlı kabul edildi. Betimleyici istatistikler olarak ortalama ve ortanca değerleri kullanıldı.

\section{BULGULAR}

Çalışmaya 31 hasta dahil edilmiştir. En genç hasta 29, en yaşı ı hasra 69 yaşında olup yaş ortalaması 52.6 yıl, ortanca yaş ise 57 yıl olarak bulunmuştur. Tüm hastalar evli olup, 28 hasta çocuk sahibiydi, üç hastanın ise çocuğu yoktu.

TKİaçısından incelendiğinde hastaların 24(\%77.4)'ünün imatinib, 6 (\%19.4)'sının nilotinib, 1 (\%3.2)'inin dasatinib kullandığı belirlenmiştir. Nilotinib ve dasatinib kullanan hastalara bakıldığında, bu tedavilerin ikincil tedavi olduğu ve daha öncesinden imatinib kullandıkları tespit edilmiştir. Nilotinib ve dasatinib kullanan bu hastalar, 8-76 ay arasında değişen sürelerde imatinib kullanmış ve yanıt kaybı nedeniyle ikinci kuşak TKi'ye geçilmiş hastalardı. Nilotinib tedavi süresi 6-26 ay arasında değişmekteydi. Dasatinib kullanım süresi ise 18 aydı. Hastaların sayısal dağılımları Tablo 3'te tedavi dozuna göre, Tablo 4'te ise ED şiddetine göre verilmiştir. On iki (\%38.7) hastada ED saptanmamış, 16 (\%51.6) hastada hafif derecede, 3 (\%9.7) hastada orta derecede disfonksiyon saptanmıştır.

İmatinib kullanan 24 hastaya baktığımızda ise yaş ortalaması $54.8 \pm 12.5$ idi. Altı (\%25) hasta 50 yaş altında, 18 (\%75) hasta 50 yaş ve üzerindeydi. Üç hasta çocuk sahibi değildi. En kısa tedavi süresi süre altı ay, en uzun 90 ay, ortalama süre $45.2 \pm 28.4$ aydı. Hastaların 4 (\%16.7)'ü 6-12 ay arasında, 5 (\%20.8)'i 12-24 ay arasında, kalan 15 (\%62.5)'i iki yıldan daha uzun süredir tedavi görmekteydi.

\section{Tablo 3. Tirozin kinaz inhibitörleri (TKi) ve hasta dağılımı}

\begin{tabular}{lcc} 
TKi & İlaç dozu (mg/gün) & Hasta dağılımı (n) \\
\hline İmatinib & 400 & 4 \\
& 600 & 17 \\
& 800 & 3 \\
Nilotinib & 600 & 2 \\
& 800 & 4 \\
Dasatinib & 100 & 1 \\
\hline
\end{tabular}

Tablo 4. Hastaların erektil disfonksiyon (ED) derecesine göre dağılımı

\begin{tabular}{lcc} 
ED & Sayı (n) & Oran (\%) \\
\hline Yok & 12 & 28.7 \\
Hafif & 16 & 51.6 \\
Orta & 3 & 9.7 \\
Toplam & 31 & 100 \\
\hline
\end{tabular}

İmatinib kullanan hastaların ED değerlendirmesinde şu sonuçlar elde edilmiştir. Hastaların 10 (\%41.5)'unda ED saptanmazken 11 (\%45.8) hastada hafif, 3 (\%12.5) hastada orta şiddette disfonksiyon vardı. Hem tüm TKi kullanan hastalara hem de imatinib kullanan hastalara bakıldığında, hiçbir hastanın ağır ED kategorisinde yer almadığı görülmüştür. İmatinibin dozlara göre değerlendirmesinde; 400 mg/gün kullanan hastaların birinde orta şiddette, sekizinde hafif şiddette ED saptanırken, beş hastada ise ED saptanmadığı görülmüştür. 600 mg/gün imatinib kullanan hastaların yine birinde orta şiddette, üçünde hafif şiddette ED bulunurken üç hastada ise ED saptanmamıştır. En yüksek doz olan 800 mg/gün imatinib kullanan hastalara bakıldığında, iki hastada ED tespit edilmemiş, birinde ise orta şiddette ED bulunmuştur. Tablo 5'te ED ile imatinib dozu, tedavi süresi ve yaş açısından dağılımları görülmektedir. ED varlığı ya da şiddeti ile ilaç dozu, tedavi süresi ve yaş arasında istatistiksel bir anlamlılık saptanmamıştır. Sırasıyla p değerleri; $0.25,0.24$ ve 0.06 bulunmuştur.

\section{TARTIŞMA ve SONUÇ}

Son 15-20 yıla kadar çeşitli tedavi modellerinin uygulandığı KML'de imatinibin tedaviye girmesiyle hem mortalite ve morbidite azalmış hem de daha yüksek oranda majör ve komplet sitogenetik yanıt elde edilmiştir (10). İmatinibe karşı primer ve sekonder direnç gelişimi, yeni TKI'lerin bulunmasına neden olmuş, ikinci ve üçüncü kuşak TKi'ler tedaviye eklenmiştir. İmatinib etkinliği, güvenliği ve yan etkileri bakımından geniş çaplı araştırmalarla değerlendirilmiştir $(11,12)$.

Bütün kemoterapötik ajanların gonadlar üzerine yan etkileri hayvan deneylerindeki bilgilerin yanında insanlarda gelişen gebeliklere ve ilaca maruz kalmış fetüs veya çocuğun uzun süreli takip sonuçlarına dayanmaktadır. Tirozin kinazların hücresel etkinlikleri göz önüne alındığında, imatinibin üreme hücreleri (spermatogonium, ovum), zigot ve fetal gelişim üzerine de etki edebileceği düşünülmektedir. İmatinib tedavisi altındaki kadınlarda gebelik gelişimi, gebelik saptananlarda fetal gelişim ve imatinib tedavisi altındaki erkeklerin üretkenliğiyle ilgili bildiriler olgu veya küçük grup sunumu bazındadır. 
Tablo 5. İmatinib kullanan hastaların doz ilişskili dağılımları

\begin{tabular}{|c|c|c|c|c|c|c|c|c|c|}
\hline & \multicolumn{2}{|c|}{ ED - Yok } & \multicolumn{2}{|c|}{ ED - Hafif } & \multicolumn{2}{|c|}{ ED - Orta } & \multicolumn{2}{|c|}{ Toplam } & \multirow[b]{2}{*}{$\mathbf{p}$} \\
\hline & $\mathbf{n}$ & $\%$ & $\mathbf{n}$ & $\%$ & $\mathbf{n}$ & $\%$ & $\mathbf{n}$ & $\%$ & \\
\hline \multicolumn{10}{|l|}{ İmatinib } \\
\hline 400 mg/gün & 5 & 20.7 & 8 & 33 & 1 & 4.1 & 14 & 58.3 & \\
\hline 600 mg/gün & 3 & 12.4 & 3 & 12.4 & 1 & 4.1 & 7 & 29.2 & \\
\hline 800 mg/gün & 2 & 8.3 & 0 & & 1 & 4.1 & 3 & 12.5 & 0.25 \\
\hline \multicolumn{10}{|l|}{ Tedavi süresi } \\
\hline 6-12 ay & 3 & 12.4 & 1 & 4.1 & 0 & & 4 & 16.7 & \\
\hline $12-24$ ay & 2 & 8.3 & 1 & 4.1 & 2 & 8.3 & 5 & 20.8 & \\
\hline 2 yıl üzeri & 5 & 20.7 & 9 & 37.4 & 1 & 4.1 & 15 & 62.5 & 0.24 \\
\hline \multicolumn{10}{|l|}{ Yaş } \\
\hline$<50$ & 5 & 20.8 & 1 & 4.1 & 0 & & 6 & 25 & \\
\hline$\geq 50$ & 5 & 20.8 & 10 & 41.6 & 3 & 12.5. & 8 & 75 & 0.06 \\
\hline Toplam & 10 & 41.5 & 11 & 45.8 & 3 & 12.5 & 24 & 100 & \\
\hline
\end{tabular}

TKi kullanımı sırasında doğurma potansiyeli olan kadınlarda gebeliklerin saptanması fertilite üzerine çeşitli teorilerin ileri sürülmesine neden olmuştur. Ancak bu konu ile ilişkili olarak yapılmış çalışma yoktur. İmatinibin anne sütüne geçtiği bilinmekle birlikte gonadlarda ilacın dağıIım oranı ile ilişkili bilgi yoktur $(4,5)$. Ayrıca imatinibin erkek fertilitesi ve erektil fonksiyonlar üzerindeki etkisini inceleyen çalışmalar ratlar düzeyinde olup, insanlarla ilişkili çalışma da mevcut değildir. Bu açıdan bakıldığında çalışmamız, imatinib tedavisi ve diğer TKI alan erkek KML'li hastalarda erektil fonksiyonu değerlendiren ilk çalışma özelliğini taşımaktadır.

Proteinleri tirozin kinaz aktivitesine sahip olan genlerden c-kit, leyding hücrelerinin gelişiminde, spermatogoniumların migrasyon, proliferasyon ve surveyinde; PDGF ve reseptör proteini ise hem leyding hücrelerinin hem de seminifer tübül miyoid hücrelerinin gelişimde önemlidir (13). Bu bilgi imatinibin c-kit ve PDGF proteinlerini de inhibe ederek erkek fertilitesi üzerine etkili olabileceğini akla getirmektedir. Nurmio ve arkadaşları imatinib uygulanan ratlarda spermatogonium proliferasyonunun azaldığını ve germ hücre apopitozisinin arttığını göstermişlerdir (13). Ayrıca testis ve epididimal ağırlığın azaldığı görülmüş fakat fertilite ve canlı doğum insidansında olumsuz bir etki kaydedilmemiştir. İnsanlara bakıldığında ise TKi kullanan erkeklerin partnerlerinde gebelik oluşumu ve normal doğumların olduğu bilinmektedir. Ülkemizden bir olgunun da imatinib kullanımı altında iken iki sağlıklı çocuğu olduğu literatürle paylaşılmıştır (4).

Ratlar üzerindeki pre-klinik güvenlik çalışmalarında, imatinibin klastojenik ve mutajenik etkisi saptanmazken teratojenik olduğu gösterilmiştir (14). Bu da imatinib alan doğurgan kadın hastalara kontrasepsiyon önerilmesine neden olmuştur. Ancak aksine ilaç maruziyeti altında oluşan gebeliklerin sağlıklı devam edebileceği ve sağlıklı bebek gelişimi olabileceği de bilinmektedir (4). Erkek hastalarda ise kontrasepsiyon yönünden dikkat edilmesi gerektiği net olarak anlaşılır değildir.

İmatinibin mutajenik ve klastojenik etkisi bilinmemektedir. Ancak Hensley ve Ford ratlarda, köpeklerde ve maymunlarda spermatogenezisin etkilendiği gösterilmiştir (15). Buna karşın Schultheis ve arkadaşları imatinibin terapötik dozlarda sperm ve folikül gelişimini etkilemediğini belirtmişlerdir. Bu çalışmada ratlara iki ay süresince 150 $\mathrm{mg} / \mathrm{kg} / \mathrm{gün}$ dozunda imatinib uygulanmış, kontrol grubu ile karşılaştırıldığında seminifer tübül çapı ve morfolojisinde anlamlı bir fark bulunmamıştır. Dişi ratların overiyal fonksiyonları, folikül sayısı ve gelişiminde de herhangi bir fark saptanmamıştır. Daubon ve arkadaşlarının çalışmalarında yaşları 26-43 arasında değişen, dördü 400 mg/gün, biri ise $600 \mathrm{mg} / \mathrm{gün}$ dozunda imatinib kullanan beş erkek hastadan oluşan gebeliklerin sağlıklı doğumla sonuçlandığı raporlanmıştır (17). Ramasay ve arkadaşları da yaşları 4146 arasında değişen, eşlerinde gebelik tespit edilene kadar ortalama 18 ay, median 216 gram imatinib maruziyeti olan dört erkek hastayı izlemişler ve sağlıklı beş doğum raporlamışlardır (18).

İmatinibin erektil ve vasküler fonksiyonlar üzerindeki etkisini inceleyen tek çalışma Gur ve arkadaşları tarafından yapılmıştır (19). Bu çalışma hiperglisemik ratlarda, yüksek serum glukoz seviyesinin erektil ve endotel fonksiyonlar üzerinde yarattığı olumsuz etkinin, imatinib ile gerileyebileceği hipotezi üzerine kurulmuştur. Streptozosin ile diyabet oluşturulan ratlardan bir gruba diyabet gelişimiyle eş zamanlı olarak $50 \mathrm{mg} / \mathrm{kg}$ imatinib uygulanmış ve koruyucu tedavi grubu kabul edilmiştir. İkinci gruba ise aynı dozda imatinib, diyabet oluşumundan dört hafta sonra uygulanmış ve bu grup da geriletici tedavi grubu olarak kabul edilmiştir. Erektil değerlendirme için in vivo şartlarda intrakavernozal basınç (IKB), ortalama arter basıncı (OAB), İKB/ 
OAB oranı, korpus kavernozum düz kas (KKDK) liflerinin izometrik gerilimi ölçülmüştür. Çalışmanın değerlendirilmesinde imatinibin erektil fonksiyonlar üzerindeki koruyucu etkisinin, bozulmuş fonksiyonları geriletici etkisinden daha güçlü olduğu kanısına varılmıştır. Bu çalışmada dikkat çeken bir özellik, hem koruyucu hem geriletici grupta kan glukozunda anlamlı derecede düşme (önleyici grup için $p<0.05$; geriletici grup için $p<0.01$ ) elde edilmesidir. İmatinibin erektil parametreler üzerinde olumlu etkisi, diyabet üzerindeki olumlu etkisinin bir sonucu gibi durmaktadır. Nitekim streptozosin ile oluşturulan diyabetin, kavernöz sinirin stimülasyonu ile oluşan erektiliteyi gerilettiği ve korpus kavernozum düz kasının gevşeme yanıtını azalttığı bilinmektedir (20). Bizim çalışmamızda yer alan hastaların diyabet dahil KML dışında bilinen bir hastalık öyküsü yoktu. En yüksek açlık kan şekeri 119 mg/dL idi. "American Diabetic Associaton (ADA)" kriterlerine göre diyabet sınırının altındaydı (21). Sekiz (\%33.3) hastanın açlık kan şekeri 100 mg/dL' nin üzerinde ölçüldü. Açlık kan şekeri üst sınırı 100 mg/dL kabul edildiğinde kan şekeri yüksekliği ile ED arasında korelasyon saptanmadı $(p=0.436)$.

Bahsedilen bütün literatür bilgileri göz önüne alındığında, imatinib ve diğer TKI'lerin erkek KML hastalarında erektil fonksiyonlar üzerine etkisini değerlendiren bir çalışmanın olmadığı görülmektedir.

Yapılan çalışmalarda ED'in ülkelere ve kültürlere göre değişkenlik gösterebileceği görülmektedir. Ülkemizde Karataş ve arkadaşları 20-40 yaş arasında 558 erkeği, demografik özellikleri, eşlik eden hipertansiyon, diyabet, hiperlipidemi, nörolojik ve psikiyatrik hastalıkları, operasyon öyküleri, ilaç, alkol ve sigara kullanım öyküleri yönünden incelemişler ve IIEF Türkçe formu ile erektil fonksiyonları değerlendirmişlerdir (22). Bu çalışmada ED prevalansı, 20-30 yaş arasında \%38.5, 30-40 yaş arasında \%32.5 oranında saptanmış ve yaş grupları arasında istatistiksel bir anlam bulunamamıştır.

İlaç kullanımı da ED etyolojisinde önemli bir yer oluşturmaktadır. ED'li olguların yaklaşık \%25'inde ilaçlar suçlanmaktadır ve bu etkinin geri dönüşümlü olduğu belirtilmektedir (23).

Çalışmamızda, hematoloji bilim dalının takip ve tedavisi altında toplam 112 olgu olduğu saptanmış olmakla birlikte, bilinen başka hastalığı, operasyon öyküsü ve TKi imatinib dışında ilaç kullanımı olan hastaların dışlanması sonucunda değerlendirmeye 24 olgu alınabilmiştir. Bulgular bölümünde bahsettiğimiz gibi imatinib kullanan hastaların biri orta, sekizi hafif olmak üzere sadece dokuzunda ED saptanmıştır. Tedavi dozu ve kullanım süresi ile anlamlı sonuç elde edilememesi öncelikle olgu sayısındaki kısıtıııkla açıklanabilir. Bunun yanında çalışmamızın diğer bir kısıtlayıcı yönü tedavi öncesi durumun değerlendirilmemiş olmasıdır. Buna rağmen imatinibin erektil fonksiyonlar üzerine etkisini değerlendiren ilk çalışma olması açısından anlamlıdır. Ayrıca bu hasta grubunda anket sorgulamasıyla birlikte serum hormon düzeyleri ya da kavernöz sinir innervasyonun incelenmesiyle daha anlamlı sonuçlar ortaya çıkacağı kanısına varılmıştır.

\section{ETIK KURUL ONAYI}

Bu çalışma, 28.09.2010 tarihinde, 2010-9/8 sayısı ile Uludağ Üniversitesi Tıp Fakültesi Etik Kurulu tarafından onaylandı.

\section{ÇIKAR ÇATIŞMASI}

Yazarların çıkar çatışması bulunmamaktadır.

\section{MALI AÇIKLAMA}

Çalışma için doğrudan veya dolaylı mali destek alınmadı. Çalışma ile ilgili herhangi bir firma veya kişi ile ilgili ticari bağlantı yoktur.

\section{YAZAR KATKISI}

Çalışma, Rıdvan Ali'nin yöneticisi olduğu, Atakan Tekinalp tarafından yazılan tezden üretilmiştir.

\section{KAYNAKLAR}

1. Baştürk B, Evke E, Tunalı A, Karakuş S. Interleukin-10 and interferon-gamma cytokine gene polymorphisms may be risk factors for chronic myelogenous leukemia. Turkish J Haemat 2005;22:191-6.

2. Sawyers CL. Chronic myeloid leukemia. N Engl J Med 1999;340:1330-40.

3. Seymour JF, Grigg A, Reynolds J, et al. Two year data from a prospective safety analyzing the consequences of imatinib mesilat inhibition of sensitive kinases other than bcr-abl in patient with previously untreated chorinic phase CML. Blood 2006;108:2147.

4. Ali R, Ozkalemkas F, Kimya Y, Koksal N, Ozkocaman V, Gulten $\mathrm{T}$, et al. Imatinib use during pregnancy and breast feeding: a case report and review of the literature. Arch Gynecol Obstet 2009;280:169-75.

5. Apperley J. Issues of imatinib and pregnancy outcome. J Natl Compr Canc Netw 2009;7:1050-8.

6. Ramasamy K, Hayden J, Lim Z, Mufti GJ, Ho AY. Successful pregnancies involving men with chronic myeloid leukaemia on imatinib therapy. Br J Haematol 2007; 137:374-5.

7. Rosen RC, Riley A, Wagner G, Osterloh IH, Kirkpatrick J, Mishra A. The International Index of Erectile Function (IIEF): a multidimensional scale for assesment of erectile dysfunction. Urology 1997;49:822-30.

8. Akkus E, Kadioglu A, Esen A, Doran S, Ergen A, Anafarta K, et al. Prevalance and correlates of erectile dysfunction in Turkey: a population-based study. Eur Urol 2002;41:298-304.

9. Stewart AL, Kamberg C. Physical functioning. In: Stewart AL, Ware J (eds). Measuring Function and Well-Being: The Medical Outcomes Study Approach. Durham: Duke University Press, 1992:243-5.

10. O'Brien SG, Guilhot F, Larson RA, Gathmann I, Baccarani M, Cervantes $F$, et al. Imatinib compared with interferon and lowdose cytarabine for newly diagnosed chronic-phase chronic myeloid leukemia. N Engl J Med 2003;348:994-1004. 
11. Druker BJ, Talpaz M, Resta DJ, Peng B, Buchdunger E, Ford JM, et al. Efficacy and safety of a specific inhibitor of the bcr-abl tyrosine kinase in chronic myeloid leukemia. N Engl J Med 2001;344:1031-7.

12. Castagnetti F, Palandri F, Amabile M, Testoni N, Luatti S, Soverini $\mathrm{S}$, et al. Results of high-dose imatinib mesylate in intermediate sokal risk chronic myeloid leukemia patients in early chronic phase: a phase 2 trial of the GIMEMA CML Working Party. Blood 2009;113:3428.

13. Nurmio M, Toppari J, Zaman F, Andersson AM, Paranko J, Söder $\mathrm{O}$, et al. Inhibition of tyrosinc kinases PDGFR and C-kit by imatinib mesylate interferes with postnatal testicular development in the rat. Int J Androl 2007;30:366-76.

14. Ault $\mathrm{P}$, Kantarjian $\mathrm{H}, \mathrm{O}^{\prime}$ Brien $\mathrm{S}$, Faderl $\mathrm{S}$, Beran $\mathrm{M}$, Rios MB, et al. Pregnancy among patients with chronic myeloid leukemia treated with imatinib. J Clin Oncol 2006;24:1204-8.

15. Hensley ML, Ford JM. Imatinib treatment: specific issues related to safety, fertility, and pregnancy. Semin Hematol 2003;40:21-5.

16. Schultheis B, Nilmeier BA, Yin H, Gosden RG, Melo JV. Imatinib mesilate at therapeutic doses has no impact on folliculogenesis or spermatogenesis in a leukaemia Mouse model. Leuk Res 2012;36:271-4.
17. Daubon T, Morel F, Kitzis A, et al. Male patients with chronic myeloid leukemia treated withimatinib involved in healthy pregnancies: Report of five cases. Leuk Res 2008;33:505-20.

18. Ramasamy K, Hayden J, Lim Z, Mufti GJ, Ho AY. Successful pregnancies involving men with chronic myeloid leukaemia on imatinib therapy. Br J Haematol 2007;137:374-5.

19. Gur S, Kadowitz PJ, Hellstrom WJ. A protein tyrosine kinase inhibitor, imatinib mesylate (Gleevec), improves erectile and vascular function secondary to a reduction of hyperglycemia in diabetic rats. J Sex Med 2010;10:3341-50.

20. Christ GJ, Hsieh Y, Zhao W, Schenk G, Venkateswarlu K, Wang $\mathrm{HZ}$, et al. Effects of streptozotocin induced diabetes on bladder and erectile (dys)function in thesame rat in vivo. BJU Int 2006;97:1076-82.

21. American Diabetes Association. Diagnosis and classification of diabetes mellitus. Diabetes Care 2010;33:62.

22. Karataş TC. Manisa kent merkezinde $20-40$ yaş arası erektil disfonksiyon prevalansı ve eşlik eden faktörler (uzmanlık tezi). Manisa: Celal Bayar Üniversitesi, 2007.

23. Keene LC, Davies PH. Drug related erectile dysfunction. Advers Drug React Toxicol Rev 1999;18:5-24. 